\title{
Alagille syndrome: Review of 14 patients
}

\author{
Purnamawati S Pujiarto,' Arnold L Smith? \\ 'Hepatology Division, Child Health Department, Medical School, University of Indonesia, Jakarta, Indonesia \\ 2Department of Gastroenterology \& Nutrition, Royal Children Hospital, Melbourne, Australia
}

\begin{abstract}
Alagille syndrome (AGS) is a common form of familial intrahepatic cholestasis, an autosomal dominant disorder due to defects in Jaggedf gene. It is characterized by at least 3 of 5 major features. We reviewed two groups of patients with AGS. Group 1 comprised 12 AGS patients, retrospectively studied (1995-1996), in the Gastroenterology Depaitment, Royal Children's Hospital, Melbourne. Group 2 comprised 2 AGS patients, prospectively studied since 1999, in The Pediatric Hepatology Division, Cipto Mangunkusumo Hosp lal, Jakarta. Prolonged cholestasis is the most common feature at presentation (12 patients). All these 12 subjects developed pruritus and xanthoma of varying degree. Osteopenia occured in 6 patients, 2 patients experienced fractures. AGS facies was noted in all 14 subjects. Heart anomaly was found in 10 patients, vertebral anomaly in 6 patients, and posterior embryotoxon in 10 patients. Common additional features were growth and mental retardation in 10 and 8 patients, respeclively. Liver biopsy was able to confirm the diagnosis as young as age 2 months. Death occurred in 2 patients due to liver failure and hemorrhagic pneumonia. I.jver transplant was done in 1 patient due to poor quality of life (severe pruritus, xanthoma, recurrent fractures). Affected family members were strongly presumed in $\mathbf{8}$ patients. In conclusion, AGS should be considered in babies with chronic intrahepatic cholestasis, especially if associated with pruritus. Liver biopsy is the most sensitive diagnostic testing which will prevent unnecessary surgical intervention due to biliary atresia mimicry. [Paediatr Indones 2000;41:47-55]
\end{abstract}

Keywords: Alagille syndrome, atteriohepatic ofsplasia, cholestasis, tiver disease, prognosis

\begin{abstract}
ArTeriohepatic DYSPlasia (AHD) or AlagLle (AGS) or syndromatic paucity of the interlobular bile ducts (SPILBD) is an autosomal dominant disorder that involves abnormalities of varying severity in multiple organ systems. It is characterized by five major features: chronic cholestasis, pulmonary artery hypoplasia or stenosis, butterfly appearance vertebrae, ocular abnormalities such as posterior ocular embryotoxon, and peculiar facies. ${ }^{1.5}$ Various minor or additional signs such as physical impairment, mental retardation, and renal disorders, may also be
\end{abstract}

Correspondence: Rusdi Andid, MD. Department of Child Health, Medical School, University of North Sumatera - Adam Malik Hospital Jl. Bunga Lau No. 17, Medan. Indonesia. Ph. 061-830341/830405/ 8830143. Fax. 061-830255. observed. ${ }^{4.67}$ AGS is one of the most common form of familial intrahepatic cholestasis. ${ }^{7.8}$ It is an autosomal dominant with reduced penetrance and variable expressivity. ${ }^{4,9.13}$ However, it is sporadic in some patients. ${ }^{14}$ Byme reported the association of AGS with an interstitial deletion of the short ann of chromosome $20,{ }^{15}$ 'later found to be located in chromosome 20 pl1.23-12.2. ${ }^{16.18}$ The varied manifestations initially lead to the hypothesis that AGS is also a contiguous gene syndrome. ${ }^{19}$ Recent data show that the phenotypic spectrum of AGS is due to defects in a single gene, Jagged l, which encodes a ligand in the developmentally important Notch intercellular signaling pathway. In 1997, Oda isolated Jagged gene (symbolized JAGI or Jaggedl) covering AGS critical region on 20p12. Thereare 3 variants, a deletion, an insertion, and a splice donor mutation. ${ }^{20}$ According to Krantz, 
the mutation is mostly due to intragenic mutation. One of several mechanisms involved in AGS is haploinsufficiency. ${ }^{21}$ However, the mechanism by which defects Jagged I cause AGS is not yet understood. . $^{1.21}$ The purpose of this study is to (1) report the major and minor features of AGS, (2) discuss the findings and the implications of diagnostic testing in infants at initial presentation, (3) deternine if clinical features predict morbidity, transplantation, or death, (4) observe family pattern of AGS patients.

\section{Patients and methods}

There werc 2 groups in this study. Group 1 was studied from July 1995 to January 1996 in the Department of
Gastrocnterology Royal Children's Hospital (RCH), Melbourne, Australia. AGS patients (12) were identified from the medical records. Data were retrospectively collected. Group 2 (2 patients) was studied prospectively since January 1999 in The Child Health Department, Medical School, University of Indonesia, Jakarta, Indoncsia. The diagnosis of AGS was based on at least three major clinical features: chronic cholestasis, cardiovascular abnormalities, vertebral anomalies, ocular anomalies, characteristic facies. One or both investigators examined the patients. Medical reports were reviewed for laboratory data, test results (echocardiogram, catheterization, and radiograph), subspecialty consultations (ophthalmology), histology reports, surgery, and family history.

TABLE 1. BASE LINE DATA AND DETAILS OF AGS CASES AT PRESENTATION AND ON FOLLOW UP

\begin{tabular}{|c|c|c|c|c|c|c|c|c|}
\hline Ca-se & F/M & $\begin{array}{l}\text { BW } \\
(\mathrm{kg})\end{array}$ & $\begin{array}{l}\text { Age } \\
\text { (wk) }\end{array}$ & Cholestasis & Heart & AGS facies & Vertebrae & Biopsy \\
\hline 1 & $M$ & 1.8 & 8 & + , persist & $\mathrm{SM}-\mathrm{P} \rightarrow \mathrm{NAD}$ & + month 18 & NAD & $\begin{array}{l}\text { NH (month 2) } \\
\text { IHBDP (month 3) }\end{array}$ \\
\hline 2 & M & 2.4 & 3 & + , persist & $\mathrm{SM}-\mathrm{P} \rightarrow \mathrm{PVS}$ & + month 5 & Butterfly & $\begin{array}{l}\text { Abscess; EHBDO (mo 3); } \\
\text { IHBDP (month 5) }\end{array}$ \\
\hline 3 & M & 2.6 & 8 & + , persist - & $\begin{array}{l}\text { SM-P, RVH } \\
\rightarrow \text { PVS }\end{array}$ & + month 3 & NAD & $\begin{array}{l}\text { Portal wide, BD proli-ferated; } \\
\text { IHBDP (mo 17) }\end{array}$ \\
\hline 4 & M & 2.5 & 6 & + , persist & $\begin{array}{l}\text { SM-P, RVH } \\
\rightarrow \text { NAD }\end{array}$ & + month 15 & Butterfly & IHBDP (month 2) \\
\hline 5 & M & 2.1 & 5 & - & SM-P; NAD & + & Butterfly & IHBDP (month 2) \\
\hline 6 & M & 2.2 & 12 & + to $\mathrm{yr} 10$ & PAS, RVH & + & $?$ & IHBDP (month 3) \\
\hline 7 & $\mathrm{~F}$ & 2.6 & 3 & + , persist & SM-P $@$ PAS,TI & + & $?$ & $\begin{array}{l}\mathrm{NH} \text { (month 2); } \\
\text { IHBDP (month 6) }\end{array}$ \\
\hline 8 & M & 1.9 & 6 & + , persist & $\begin{array}{l}\text { PVS, BAV } \\
\text { ASD }\end{array}$ & + month 3 & $?$ & $\begin{array}{l}\text { Fibrosis (month 2); IHBDP, } \\
\text { NH (month 6) }\end{array}$ \\
\hline 9 & $\mathrm{~F}$ & $?$ & 4 & + , persist & $\begin{array}{l}\text { SMP } \rightarrow \text { PHA, } \\
\text { PDA, ASD }\end{array}$ & + & NAD & $\begin{array}{l}\mathrm{NH} \text {; ?IHBDP (month 1) } \\
\text { IHBDP (month 2) }\end{array}$ \\
\hline 10 & $\mathrm{~F}$ & 2.1 & 24 & - & PPS, ASD & + month 10 & $?$ & IHBDP (month 10) \\
\hline 11 & $\mathrm{~F}$ & 2.9 & 8 & + , persist & $\begin{array}{l}\text { PDA, PAS, } \\
\text { RVH }\end{array}$ & + month 6 & Butterfly & $\begin{array}{l}\mathrm{NH} \text {; ?IHBDP (month 2); } \\
\mathrm{NH} \text { (month 3) }\end{array}$ \\
\hline 12 & $\mathrm{~F}$ & $?$ & 24 & + to yr 2 & SM-P @PVS & + & NAD & IHBDP (month 6) \\
\hline 13 & $M$ & 2.8 & 13 & + , persist & PAS diffuse & + month 10 & Butterfly & IHBDP (month 13) \\
\hline 14 & $\mathrm{~F}$ & 2.5 & 16 & + , persist & NAD & + & NAD & Refused \\
\hline
\end{tabular}

Abbreviations: $M=$ male; $F=$ female; $S M=$ systolic murmur; $P V S=$ pulmonary valve stenosis, $R$ VH = right ventricular hypertrophy: $P A S=$ pulmonary artery stenosis; $\mathrm{TI}=$ tricuspid insufficiency; $\mathrm{IHBDP}=$ intrahepatic biliary dysplasia; $\mathrm{EHBDO}=$ extrahepatic biliary duct obstruction; ASD = atrial septal defect; NAD = no abnormality detected 
TABLE 2. MAJOR FEATURES AND OTHER ABNORMALITIES OF AGS ON FOLLOW UP

\begin{tabular}{|c|c|c|c|c|c|c|}
\hline & Pruritus & Xanthoma & Skeletal & Eyes & Additional features & Outcome \\
\hline 1 & $\begin{array}{l}\text { Month } 13 \\
\text { persist }\end{array}$ & Month $18-48$ & $\begin{array}{l}\text { Porosis month } 18 \text {, } \\
\text { Fracture yr } 5,15\end{array}$ & $\begin{array}{l}\text { BPE, } \\
\text { PEA }\end{array}$ & $\begin{array}{l}\text { GR,MA, VUR Perthes, } \\
\text { behaviour problem }\end{array}$ & Severe \\
\hline 2 & $\begin{array}{l}\text { Month } 13 \\
\text { persist }\end{array}$ & Month $5-50$ & $\begin{array}{l}\text { Ricketts } \\
\text { month } 8\end{array}$ & $?$ & $\begin{array}{l}\text { MR, haematemesis, } \\
\text { encephalopathy, migraine, }\end{array}$ & Died \\
\hline 3 & $\begin{array}{l}\text { Month } 12 \\
\text { Persist }\end{array}$ & $\begin{array}{l}\text { Month } 17 \text { to } \\
\text { yr } 5\end{array}$ & $\begin{array}{l}\text { Fracture } \\
\text { month 24, } \\
\text { JRA yr } 4\end{array}$ & $?$ & $\begin{array}{l}\text { GR, MR, polydipsia, polyuria, } \\
\text { ICP, FMN, hearing } \downarrow\end{array}$ & Died \\
\hline 4 & $\begin{array}{l}\text { Month } 36- \\
48 \text {, Mild }\end{array}$ & No & No & BPE & $\begin{array}{l}\text { GR, MR, behaviour, hearing } \downarrow \text {. } \\
\text { benign ICP }\end{array}$ & Mild \\
\hline 5 & $\begin{array}{l}\text { Month 12- } \\
40 \text {, mild }\end{array}$ & No & No & BPE & $\begin{array}{l}\text { Benign ICP, renal } \\
\text { echogenicity - }\end{array}$ & Very mild \\
\hline 6 & $\begin{array}{l}\text { Month } 11 \\
\text { Persist }\end{array}$ & $\begin{array}{l}\text { Month } 12 \text { - } \\
\text { Yr } 10\end{array}$ & $\begin{array}{l}\text { Arthritis (month 12), } \\
\text { clynodactilia, }\end{array}$ & $?$ & $\begin{array}{l}\text { Recurrent UTI, small kidneys, } \\
\text { hearing } \downarrow \text {, GR, MR }\end{array}$ & Severe \\
\hline 7 & $\begin{array}{l}\text { Month } 6 \text { - } \\
\text { persist }\end{array}$ & Month $18-30$ & No & BPE PR, & $\begin{array}{l}\text { Scoliosis, inguinal hemia, } \\
\text { enuresis }\end{array}$ & Severe \\
\hline 8 & $\begin{array}{l}\text { Month } 6 \text { - } \\
\text { persist }\end{array}$ & $\begin{array}{l}\text { Month } 36-78 \text {; } \\
\text { Month } 90\end{array}$ & $\begin{array}{l}\text { Osteopenia } \\
\text { month } 60\end{array}$ & BPE, PR & $\begin{array}{l}\text { GR, MR, headache, } \\
\text { hearing } \downarrow \text {, photosensitivity }\end{array}$ & Severe \\
\hline 9 & $\begin{array}{l}\text { Month } 10- \\
\text { persist }\end{array}$ & $\begin{array}{l}\text { Month } 14 \text { - } \\
\text { persist }\end{array}$ & Not detected & BPE & GR, MR & Mode-rate \\
\hline 10 & No & No & No & BPE & & Mild \\
\hline 11 & $\begin{array}{l}\text { Month } 12 \text {. } \\
\text { mild }\end{array}$ & No & $\begin{array}{l}\text { Osteopenia } \\
\text { month } 12\end{array}$ & BPE, PR & $\begin{array}{l}\text { Tracheomalacia, ICP } \\
\text { GR, MR, Picketts }\end{array}$ & Mode-rate \\
\hline 12 & No & No & No & Left PE & - & Very mild \\
\hline 13 & Month 9 & Month 13 & No & NAD & GR & Mode-rate \\
\hline 14 & $\begin{array}{l}\text { Month } \\
12 \text { mild }\end{array}$ & $\begin{array}{l}\text { Month } 13 \text { - } \\
\text { mild }\end{array}$ & No & BPE & GR, MR & Mode-rate \\
\hline
\end{tabular}

$\mathrm{NAD}=$ no abnormalities detected; $\mathrm{BPE}=$ bilateral posterior embryotoxon; $\mathrm{GR}=$ growth retardation; $\mathrm{TI}=$ tricuspid insufficiency:

$\mathrm{PAH}=$ : pulmonary artery hypoplasia; $\mathrm{MR}=$ mental retardation; FMN = focal membranous nephritis; ICP $=$ increased intracranial pressure $\mathrm{UT} \mid=$ urinary tract infection; $\mathrm{PR}=$ pigmentary retinopathy; $\mathrm{PEA}=$ pigment epithel atrophy; JRA = juvenile rheumatoid arthritis

Chronic cholestasis was defined as persistent elevation of conjugated bilirubin ( $\geq 1.0 \mathrm{mg} / \mathrm{dl}$ ) beyond 6 months of age. Characteristic facies was defined by the investigators. A pathologist at the referral center examincd the liver specimen. A ratio of interlobular bile ducts to portal tract $<0.4$ was used to define paucity. Adequate estimation of this ratio had been reported to require 10 portal tracts. Needle biopsies rarely contained this number, but the diagnosis could be made with fewer portal tracts in most patients.

\section{Results}

There were 12 patients in Group 1, 7 boys and 5 girls, and 2 patients in Group 2 (paticnts 13 and 14), one boy and one girl. Age at referral ranged from 3 to 24 weeks, 9 patients at $3-10$ weeks, 3 patients at $11-16$ weeks, and 2 patients at 24 weeks. Table 1 shows data of major features. Most (12) patients wcre referred due to prolonged jaundice, only 2 were due to heart murmur (patient $5 \& 10$ ). Patient 8 was initially referred at 12 days old due to heart murnur and poor feeding, however, he was again referred at 6 weeks old because of prolonged cholestasis. Besides the 5 major features, some patients developed other features of AGS. See Table 2 for details.

\section{Major features of AGS}

Chronic cholestasis was the major symptom at presentation (12 paticnts). In Group 1, cholestasis was 
noted in 10 patients. It appeared at birth up to 24 days old; it became milder in some patients and was no longer detected in patients 6 and 12, at age 10 and 2 years, respectively. In Group 2, patients 13 and 14 were cholestatic since the age 10 and 60 days, respectively (Table 1).

Pruritus developed in 12 patients. In Group 1, it occurred at less than 1 year old in 4 patients, the youngest was 6 months (patients $7 \& 8$ ), between 13 - 24 months in 4 patients, at age 36 and 40 months in 2 patients. It was periodic and mild in patients 5 and 11 , very progressively in patients 3,4 and 8 . Group 2 were pruritic moderately at months $9 \& 13$ (Table 2).

Xanthoma developed in 7 and 2 patients of Groups 1 and 2, respectively, mostly at age 12-18 months. The earliest was at age 5 months. Patients 7 and 8 had severe xanthoma; it worsened in patient 8 at month 60, then disappeared but reappeared at month 90. In patients 7,1 and 2, it disappeared at age $18,30,18$ months, respectively. Group 2 developed moderate xanthoma along with pruritus (Table 2). Osteopenia developed in 6 patients of Group 1. Osteoporosis was mild in patients 3 and 8 , severe in patients 1,2 , and 3. Patient 1 had fracture at age 5 and 15 years. Patient 3 developed progressive juvenile rheumatoid arthritis (JRA) 4 years old. None of patients in Group 2 showed signs of osteopenia.

Cardiovascular abnormalities. In Group 1, systolic murmur was initially noted in 8 patients. Later, abnormalities were seen in 9 patients, i.e., pulmonary artery stenosis in 3 patients, pulmonary artery hypertension in 2 patients, and pulmonary valve stenosis in 4 patients. Four patients $(8,9,10$, and 11$)$ showed mul. tiple abnormalities. In Group 2, patient 13 showed diffuse marked peripheral arterial stenosis (Table 1).

Vertebral anomalies. Vertebral abnormalities were found in 6 patients. In Group 1, four patients with butterfly appearance of thoracic vertebrae and 1 patient with asymmetry of 5 th lumbar pedicle. No record in the other 4 patienrs. Both patients in Group 2 showed butterfly appearance.

Ophthalmologic abnormalities. Posterior embryotoxon (PE) was found in 10 of 14 patients. In Group 1, PE was present in 9 patients (patient 1 with pigment epithelial atrophy; patient 8 , bilateral pigmentary retinopathy and choroidal sclerosis; patient 7 , eccentric left pupil, mottled appearance of retinal pigment; patient 12, left PE), one patient with optic disc drusen. No information was mentioned in 3 patients.

Facies. In Group 1, AGS facies was initially noted in 5 patients (aged 3, 4, 5, 12 and 24 weeks). It was then noted in all subjects. In Group 2, it was later noted (months $9 \& 13$ ).

\section{Additional features}

Genitourinary tract abnormalities. Five patients in Group 1 developed symptoms of urinary tract abnormalities. Patient 1 had reflux and bladder diverticula, undescended testis, small genitalia, with enuresisencopresis. Patients $5 \& 6$ showed increased kidney echogenicity of unknown origin. Patient 3 had nortnal renal US. In Group 2, renal ultrasound did not show abnormalities.

Growth retardation (GR). GR was noted in 10 patients of Group 1. Seven patients were born small for date, 3 were born appropriate for age. GR was first noticed as early as 6 weeks of age, GR was detected at month in 1 patient requiring nasogastric tube feeding. Both patients in Group 2 were born appropriate for gestational age but both showed evidence of GR.

Delayed development. Motoric-mental retardation (MR) were documented in 8 patients in Group 1. Severe and mild motoric delay were observed in 6 \& 2 patients, respectively. MR was documented in 6 patients. Mild MR in 4 patients ( 3 coped well with school, including 1 patient with social inappropriateness and encopresis). Severe MR with behavioral problems (encopresis, enuresis, school refusal) in the other 2 patients needing special school. Group 2, shows mild motoric delay with appropriate mental status.

Other features. Increased intracranial pressure (ICP) was observed in 4 patients of Group 1 with no marked neurological problems. There was no evidence of ICP in Group 2. Hearing impairment occurred in patients 4, 6, and 8 (Group 1) and patient 14 (Group 2). Arthritis occurred in patients 36 of Group 1. Behavioral problems was documented in 3 patients ( 1 , $4,7)$. Patient 1 continued to have behavioral problems such as enuresis, encopresis and school refusal. As a teenager he was a heavy drinker. Currently he is unemployed and seen by adult gastroenterologist. $\mathrm{Pa}$ tient 4 showed aggressive behavior and encopresis.

\section{Diagnostic testing}

Hepatobiliary scintigraphy was done in patients 8 and 9. In patient 8 , it showed poor uptake and no 
visualization of contrast in the gut lumen after 4 hours. At 15 months old, due to severe cholestasis, ERCP was done, showing hypoplasia of common bile duct and common hepatic ducts without extrahepatic obstruction. In patient 9 , scintigraphy was normal. Cholangiography was performed for clinical suspicion of biliary atresia in patients 1 and 2, which showed normal patent extrahepatic bile ducts.

Hepatic histopathology. Intrahepatic biliary dysplasia (lHBDP) was observed at age $\leq 3$ months in 7 patients, at 3.6 months in 3 patients, $>6$ months in other 3 patients. In 7 patients, the first biopsy was able to confirm IHBDP at age 7 wecks to 13 months. Six patients had more than onc biopsy. IHBDP was confirmed after 2 nd biopsy in 3 paticnts ( 2 patients at age 3 months, 1 patient at 17 months), after 3 rd biopsy in 3 patients (aged 6 wecks, 5 months, 6 months). Patient 14 refused biopsy.

\section{Outcome}

Transplantation. Patient 8 had liver transplantation in 1996 at age 9 years. Beforehand, he had very poor quality of life due to severe pruritus, xanthoma, and recurrent fractures.

Mortality. Death occurred in patients 2 and 3. Patient 2 died at 22 years old due to liver failure with encephal@pathy. At 19 years old he had severe hematomyelis melena and a year later, he developed first episode of encephalopathy. Autopsy documented cirrhosis with abscess, pleural-pericardial effusion, pneumonia, and pulmonary valve stenosis (PVS). Patient 3 died at ge 9 years due to hemorrhagic pneumonia. He experienced fever and upper right quadrant abdominal pain. Laparotomy did not find the cause, but appendicectomy was done. Within ovemight, chest $\mathrm{x}$-ray showed progressive opacity.

Prognosis. Group 1, one of the two patients who died had severe congenital heart disease of diffuse PVS. Among the 10 survivors, 5 patients were getting worse and have poor quality of life (patients $1,7,8,9,11$ ). Four of them with multiple major structural congenital heart anomaly. Three patients were slightly better (patients 4, 5, 10), the first 2 without heart anomalies. The other 2 patients remained stable (patients 6,12 ) with mild to moderate heart anomaly. In Group 2, both two patients seem to be stable. However, patient 13 was with diffuse outcome.

\section{Family pattern}

Family history was observed in 8 patients. No family members of patients $2,7,11$, and 12 , seem to be affected. In patient 2 , no family members showed AGS manifestations but his brother and mother showed low intellectuality. Brother also noted to be of short stature. Family history in patient $1 \& 9$ was also unclear but the patemal grandmother of patient 1 had a history of liver disease and gallstones. In patient 9, there were no family members with jaundice. However, her paternal aunt, her father's cousin, and her paternal grand-mother had chronic pruritus and her paternal great grandfather had heart murmur. Patients 3, 4, and 5 were siblings. They have a sibling with AGS facies and cardiac murmur. The father experienced poor weight gain, jaundice, itching during infancy. Scarred kidney was noted later. His sister has a boy with AGS facies and pulmonary stenosis. The proband's father and aunt are with AGS facies and PVS murmur. Paternal grandmother had AGS facics and PVS murmur. The paternal great grandfather had AGS facies and systolic murmur of pulmonary artery stenosis (PAS). Sce Figure 1.

(Lca: liver cancer; GS: gall stones; P: pruritus) Patient 6 also has affected family members. He has a 12 year old sister with cardiac murmur. The mother has AGS facies and his maternal grandmother had prolong jaundice, gallstones, and with the same facies as his mother. She also had a brother with gallstones. The maternal grcat grandmother died due to liver cancer (Figure 2). In patient 8 , the father showed typical facies and history of jaundice during infancy, and his brother had cardiac murmur (Figure 3). $\mathrm{Pa}$ -

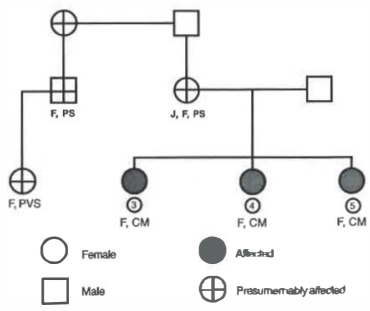

Figure 1. Family pedigree of patients $3,4,5$ 


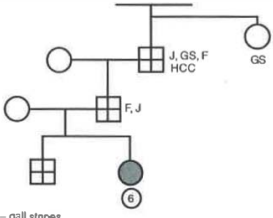

GS = gall stones

$\mathrm{HCC}=$ Iiver cancer

Figure 2. Family pedigree of case 6

tient 10 , the mother and maternal grandmother were with AGS facies. He also has a cousin with jaundice and pruritus (Figure 4).

In Group 2, patient 13 is without affected family members. The mother of patient 14 shows AGS facies. Maternal grandfather had gallstones and suffers from congenital heart disease.

\section{Discussion}

AGS is caused by mutations in Jaggedl gene, which encodes a cell surface ligand for one of the four known human Notch transmembrane receptors. The Notch signaling pathway is involved in ccll fate determination in varied tissues. Jagged-Notch interactions appear to be necessary for cardiac, hepatic, ocular, renal, skelctal, pancreatic development. Defects in

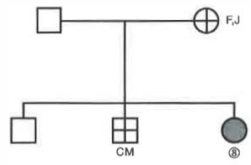

Figure 3. Family pedigree of case 8

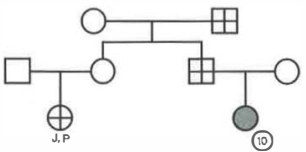

$P$ : pruritus

Figure 4. Family pedigree of case 10

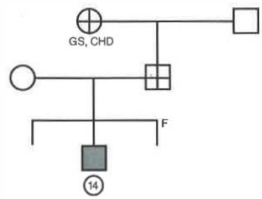

Figure 5. Family pedigree of case 14

this system produces varied pattern of abnormality in any organs. The role of the Notch signaling proteins in human development and disease is poorly understood. Studies on the pathophysiology of the abnormal signaling pathway, are needed. ${ }^{13}$

\section{Clinical features}

This study shows varied presentations and severity of AGS. At presentation, 3 paticnts showed 5 major manifestations, 7 with 4 manifestations, consistent with prior reports that the majority of AGS are with 4 manifestations. ${ }^{2,3}$ There are 2 non cholestatic patients with mild AGS. Varying degree of pruritus was noted in 12 cholestatic patients, except in those 2 patients, mostly appeared at 13 months and in 9 patients it persisted despite treatment. The earliest appcarance was at age 6 months, only 1 patient had it at age 3 . Pruritus seems to be related to the severity of the liver discase. Xanthoma mostly developed during the $2^{\text {nd }}$ year of life; it was associated with high levels of 
cholesterol..$^{8.10}$ Severe osteoporosis with fracture occurred in 3 patients. The degree of osteopenia seems to be related to the severity of liver disease. Patient $13 \& 14$ may be protected against its early occurrence due to living in a tropical country. Varied heart problems were found in 10 patients, 4 with multiple anomalies. However, autopsy of patient 3 did not show heart anomaly. Heart anomaly is said to be related to mortality; unfortunately, the 7 of 8 patients belonged to Group 1 studied retrospectively. AGS facies was mostly observed at $>3$ months. Its earliest finding was at week 3 in patient 7 who was severely cholestatic. AGS facies was also noted quite early (week 6) in patient 4 and 5, because their older sibling was aiready known as AGS.

The most common additional feature was growth and mental retardation ( 9 patients). They were born full-term, mostly weighed $<2.7 \mathrm{~kg}$ and the smallest was $1.9 \mathrm{~kg}$. This antenatal GR continued, they remained below or at $3^{\text {sd }}$ percentile. The GR may be due to chronic cholestasis. On the other hand, some investigators state that the AGS gene is located close to growth hormone (GH) gene. ${ }^{25}$ However, GH did not improve the growth of patients 6 and 8 . It is hypothesized that mesodermal defect has a role in the pathogenesis of AGS, which explains the insensitiv ity to Gill. Lack of IGF-1 was also reported, AGS patients may benefit from IGF-1 treatment. ${ }^{24}$ Motoric and mental delay was documented in 8 and 6 patients, respectively. Besides mental retardation, 3 patients developed behavioral problems. Alagille reported the same finding. ${ }^{4}$ However, it is unclear whether this is organic or due to chronic illness.

Optic disk swelling is documented in 4 patients as well as in the father of the 3 siblings. The cause is unclear, there was no evidence of increased intracra. nial pressure. ${ }^{23}$ Unlike recent report, no evidence of intracranial hemorrhage happened in this study. 27.28 Some patients developed conductive hearing problem of unknown cause. It may be due to xanthoma deposition, though some patients are with absence of the posterior/anterior semicircular canal which some. times is associated with middle ear inflammation. ${ }^{12.13}$

\section{Diagnostic testing}

The most sensitive diagnostic test of AGS is liver biopsy with the finding of IHBDP. In this study, the youngest patient that IHBDP was noted aged 8 week. Biopsy at age 4 weeks (patient 9) said to be of neonatal hepatitis but pussibility of AGS was hinted. Liver biopsy done at 1 month old, often is unable to reveal IHBDP. As is in other studies, analysis of sequential biopsy specimens proves that paucity does develop with increasing age. Several theories regarding the pathogenesis of diminished duct number in AGS, include a developmental lack of bile ducts vs a loss of previously normal ducts. The mechanism is proposed to be related to postnatal development of the terminal branches of the bile ducts in the growing liver secondary to a defect in gene Jagged $1 .{ }^{\prime}$

\section{Outcome}

The most severe form of AGS was noted in 5 patients. Death occurred in patient 2 and 3. Patient 2 died due to liver failure at age 22 years old, after the second episode of encephalopathy. Patient 3 died due to severe hemorrhagic pneumonia. Both these two patients had severe form of AGS. Due to limited number of subjects, it is difficult to identify predictor factors that affect the outcome of AGS. Severity of the hepatic disease seems to be the major cause of morbidity and mortality. Complete AGS features also seem to be related to poorer outcome compared to incomplete AGS. ${ }^{\text {i.t. }}$ it is unclear whether cardiac problems play a role in mortality, as mentioned in other study.' The outcome of the diffuse stenosis of the pulmonary artery (including the peripheral branches) in patient 13, will be interesting to observe. The overall probability of survival to age 20 years is said to be $80 \%$ in patients who do not require transplantation. Other study states that in those with onset of cholestasis in early infancy, the predicted probability of reaching age 19 years without transplantation is $50 \%,{ }^{29,30} \mathrm{In}$ addition, a study shows that some AGS children have higher risk for HCC." Some AGS children have to end up in liver transplantation unit due to liver failure or poor quality of life such as severe pruritus and/or xanthoma, recurrent fractures. ${ }^{30}$ In Group 1, patient 8 had liver transplant at age 9 years due to poor quality of life. In this study, it is not feasible to follow the remaining 10 patients of Group 1.

\section{Family pattern}

In 6 patients, family history of AGS was documented, particularly in the three siblings (patients $3,4,5$ ). Those with affected family members are those with 
TABLE 3. CHRONIC CHOLESTASIS AND ITS COMPLICATIONS

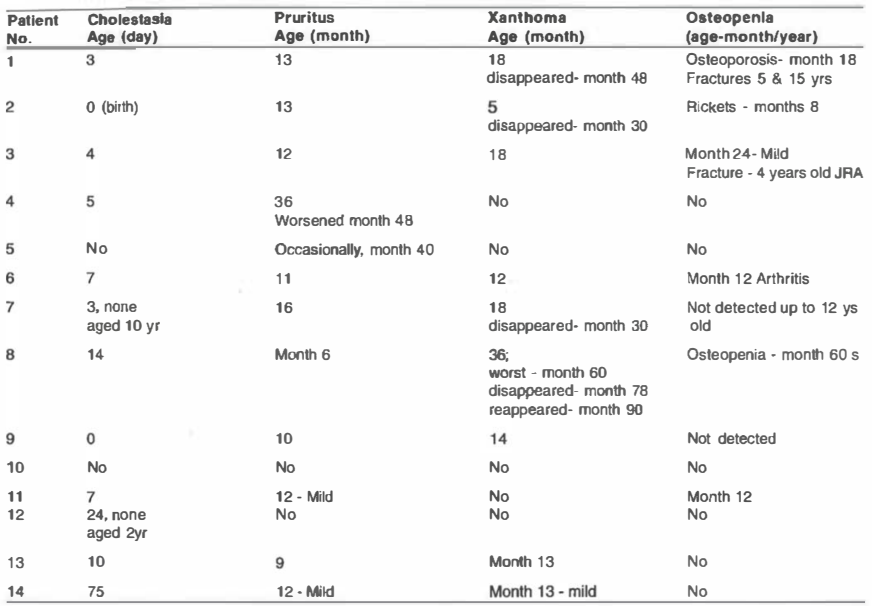

JPA: Juvenile theumatoid arthritis

complete/severe form of AGS. It is clear that affected family members of AGS patients, show minor forms of the syndrome and do not meet diagnostic criteria. However, study showed that in some of the families with minor forns of AGS, mutations of Jagged 1 have been confirmed. Further study will identify family members with less significant or subclinical disease. ${ }^{1.11}$

\section{Conclusion}

Physicians need to be aware of AGS in order to prevent unnecessary surgical intervention. It may be difficult to recognize AGS because of its varied clinical presentations including in those with subclinical disease. Initial DISIDA scan, cholangiogram, and liver biopsy in AGS infants may mimic biliary atresia. However, AGS should be considered in babies with chronic intrahepatic cholestasis especially in those with pruritus. Identifying syndromic features in the proband and probing for affected family members, are important. AGS is also possible in some patients with congenital heart disease (CHD). A study that screened patients with isolated feature such as CHD, was able to identify defects in Jaggedl gene. Studies of patients with ocular, renal, and pancreatic disease may produce similar results and will broaden the spectrum of diseases associated with Jagged 1 defects. The clinical Alagille syndrome will likely be only one of the many phenotypes caused by defects in Jagged 1 .

\section{Acknowledgments}

The authors thank Prof. Dr. G. Cleghorn for his literature help, and Ms Anne Peace for her administrative help. 


\section{References}

1. Emerick KM, Rand EB, Goldmuntz E, Krantz WD, Spinner NB, Piccoli DA. Features of Alagille syndrome in 92 patienws. Heparology 1999;29:822-9.

2. Alagille D, Odievre M, Gautier M, Dommergues JP. Hepatic ductular hypoplasia associated with characteristic facies, vertebral malformations, mental and sexual development, and cardiac murmur. J Pediatr 1975;86:63-8.

3. Watson GH, Miller V. Arteriohepatic dysplasia. Familial pulmonary atresial stenosis with neonatal liver disease. Arch Dis Child 1973;48:459-66.

4. Alagille D, Estrada A, Hadchouel M, et al. Syndromic Paucity of interlobular bile ducts: Review of 80 patients. J Pediatr 1987;110:195-200.

5. Riely CA. Familial intrahepatic cholestasis syndrome. Semin liver Dis 1987;7:119-33.

6. Poley JR. Syndromes of neonatal cholestasis. In: Gracey $M$, Burke $V$, editors. Pediatric gastroenterology and hepatology. 3rded. Boston: Blackwell Scientific Publications, 1993:556-92.

7. Mowatt AP. Hepatitis and cholcstasis in Infancy: Intrahepatic disorders. In: Mowatt AP, editor. liver disorders in childhood, 3rd ed. Oxford Butterworth Heinemann, 1994:59-73.

8. Tunessen D. Denouncement and discussion. Alagille syndrome (arteriohepatic dysplasia). Arch Pediarr Adolesc Med 1994; 148:288.

9. Desmaze C, Deleuze JF, Dutrilaux AM, Thomas G, Hadchouel M, Aurias A. Screening of microdeletions of chromosome 20 in patients with Alagille syndtome. J Med Genet 1992;29:233-5.

10. Mueller RF, Pagon RA, Pepin MG, Haas JE, Kawabori I, Stevenson JG. Arteriohepaticdysplasia: Phenotypic features and family studies. Clin Genetics 1984;19:323-31.

11. Shulman SA, Hyams JS, Gunta R. Arteriohepatic dysplasia (Alagille syndrome): Extreme variability among affected family members. Am J Med Genet 1984; 19:325-32.

12. Riely CA, Ctlier E, Jensen PS, Klatskin G. Arteriohepatic dysplasia; A benign syndrome of intrahepatic cholestasis with multiple organ involvement. Ann Intern Med 1979;91:520-7.

13. Byrne JLB, Harrod MJE, Friedman JM, Howard. Peebles PN. Del(20p) with manifestations of arteriohepatic dysplasia. Am J Mcd Genet 1986; 24:673-8.

14. Crosnicr C, Driancourt C, Raynaud N, Dhorne-Pollet $\mathrm{S}$, Pollet N, Bernard O, et al. Mutations in JAGGEDI gene are predominantly sporadic in Alagille syndrome. Gastroenterology 1999;116:1141-8.

15. Zhang F, Deleuze JF, Aurias A, Dutriliaux AM, Hugon $\mathrm{RN}$, Alagille $\mathrm{D}$, et al. Interstitial deletion of the short ann of chromosome 20 in artcriohepatic dysplasia (Alagille syndrome).J Pediatr 1990;116:73-7.
16. Dhorne-Pollet S, Deleuze JF, Hadchouel M, BonaitiPellie C.Segregation analysis of Alagille syndrome. J Med Genet 1994;31:453-7.

17. Schnittger $S$, Hofers $C$, Heidelmann $P$ et al. Molecular and cytogenetic analysis of an interstitial 20p deletion associated with syndromic intrahepatic ductular hypoplasia (Alagille syndrome). Hum Genet 1989;83:239-44.

16. Anad F Burn J, Matthews D, Cross I, Davison BCC, Mueller R et al. Alagille syndrome and deletion of 20p. J MedGenet 1990;27:729-37.

18. Schmikel RD. Contiguous gene syndromes: A component of a recognize syndromes. Medical progress. J Pediatr 1986;109:231-40.

19. Oda T, ElkahlounAG, Meltzer PS, Chandrasekharappa SC. Identification and cloning of the human homolog (JAGLI) of the rat jagged gene from the Alagille syndrome critical regionat 20p12. Genomics 1997;43:376-9.

20. Krantz ID, Colliton RP, Genin A, Rand EB, Li L, Piccoli DA, Spinner NB. Spectrum and frequency of jaggedl (JAGI) mutations in Alagille syndrome patients and their families. AmJ Hum Genet 1998;62:1361-9.

21. Silengo M, Bell GL, Biagioli M, Franceshini P. Partial deletion of the short arm of chromosome 20:46, XX, del (20) (pll)/46,XX,mocaicism. Clin Genet 1988;33:108-10.

22. Wells KK, Pulido]S, Judisch GF, Ossoinig KC, Fisher TC, LaBreque DR. Ophthalmic features of Alagille syndrome (arteriohepatic dysplasia). J Pediatr Opthalmol Sura. bisnus 1993;30:130-5.

23. Rodriguez JL, Rivera T, Palacios J. Alagille syndrome associated with caudal dysplasia sequence. Am J MedGenet $1991 ; 40: 61-4$.

24. Bucuvalas JC, Hom JA, Carisson L, Balistreri WF, Chemausek SD. Growth hormone insensitivity associated with elevated circulating growth hornone-binding protein in children with Alagille syndrome and short stanıre. JClin Endocrinol Merab 1993;76:1477-82.

25. Berman MD, Ishak KG, Schaefer EJ, et al. Syndromatic hepatic ductular hypoplasia (arteriohepatic dysplasia). A clinical and hepatic histology study of threc patients. Dig Dis Sci 1981;26:485-97.

26. Alpan G, Glick B, Peleg O, Eyal F. Pseudotumor cerebri and coma in vitamin D dependent rickets. Clin Pediatr 1991;30:254-6.

27. DeJong AR, Callahan CA, Weiss J. Pseudotumor cerebri and nutritional rickets. Eiur J Pediatr 1985;143:219-20.

26. Hoffenberg EJ, Narkewicz MR, Sondheimer JM, et al. Outcome of syndromic paucity of interlobular duct with onset of cholestasis in infancy. J Pediatr 1995; 127:220-4.

29. Tzakis AG, Reyes J, Tepetes K et al. Liver transplantarion for Alagille syndrome. Arch Surg 1993;129:337-9.

30. Kaufman SS, Wood RP, Shaw BW, et al. Hepatocarcinoma in a child with the Alagille syndrome. AJDC 1987;141:698-700. 